DOI: https://doi.org/10.47405/mjssh.v6i7.886

\begin{tabular}{|c|c|}
\hline 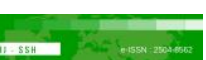 & Malaysian Journal of Social Sciences and Humanities (MJSSH) \\
\hline Malaysian Journal of & Volume 6, Issue 7, July 2021 \\
\hline (MJ-sSH) & e-ISSN : 2504-8562 \\
\hline & $\begin{array}{l}\text { Journal home page: } \\
\text { www.msocialsciences.com }\end{array}$ \\
\hline
\end{tabular}

\title{
Pengaruh Kepimpinan Distributif Terhadap Motivasi Guru: Suatu Pemerhatian Awal
}

\author{
Indira Krishnan 1 \\ 1Fakulti Pengurusan Ekonomi, Universiti Pendidikan Sultan Idris (UPSI) \\ Correspondence: Indira Krishnan (indira3911@gmail.com)
}

\begin{abstract}
Abstrak
Amalan kepimpinan adalah antara salah satu elemen penting yang dalam menentukan kecemerlangan murid dan sekolah. Justeru itu, artikel ini memberi fokus pada ulasan tentang kepimpinan distributif dalam kalangan kepimpinan sekolah. Selain membincangkan konsep kepimpinan, teori-teori yang berkaitan, artikel ini turut membincangkan pengaruh kepimpinan distributif ke atas motivasi guru berdasarkan literatur lepas.
\end{abstract}

Kata kunci: kepimpinan distributif, motivasi, motivasi guru

\section{The Influence of Distributive Leadership on Teacher Motivation: A Preliminary Observation}

\begin{abstract}
Leadership practice is one of the important elements in determining the excellence of students and schools. Therefore, this article focuses on a review of distributive leadership among school leaders. In addition to discussing the concept of leadership, related theories, this article also discusses the influence of distributive leadership on teacher motivation based on past literature.
\end{abstract}

Keywords: distributive leadership, motivation, teacher motivation

\section{Pengenalan}

Globalisasi yang pantas di dunia pada masa kini mengakibatkan pembaharuan dalam semua bidang termasuk bidang pendidikan yang menjadi nadi kepada seluruh dunia (Muhyiddin Yassin, 2013). Kementerian Pendidikan Malaysia telah menggubal Pelan Pembangunan Pendidikan Malaysia (PPPM) 2013-2025 bagi mentransformasikan sistem pendidikan ke tahap yang lebih cemerlang dan efektif (KPM, 2013). Bush dan Ng (2019), menyatakan bahawa semua organisasi pendidikan termasuk sekolah perlu membuat transformasi dalam amalan kepimpinan biasa ataupun tradisional kepada satu model kepimpinan yang terbaru iaitu kepimpinan distributif yang menjadi amalan kepada negara-negara lain pada masa kini. Jamallulail et al. (2013) menyatakan bahawa pemimpin sekolah dan guru-guru tidak 
peka dengan kepimpinan distributif kerana ia merupakan sebuah konsep yang baharu dan asing bagi mereka.

Seseorang guru besar memikul pelbagai tugas dan tanggungjawab. Oleh itu, guru besar perlu menyebar luas dan berkongsi tanggungjawab tersebut kepada guru-guru sekolah di bawahnya. Pelbagai pemimpin diperlukan bagi di setiap peringkat organisasi bagi mencapai perkembangan yang maju dalam sesebuah organisasi (Fullan, 2006). Justeru, pemimpin pada masa kini memerlukan kerjasama daripada semua pihak dalam sesebuah organisasi kerana pemimpin tidak mampu bergerak secara bersendirian dalam menghadapi cabaran serta tuntutan semasa (Ejimabo, 2015; Siva \& Khuan, 2014; Norasmah \& Rofilah, 2013).

Kepimpinan yang unggul menjadi tunjang kepada motivasi diri dalam sesebuah organisasi. Mad Shah (2006), menyatakan bahawa pengertian bagi konsep motivasi sebagai keputusan daripada pemprosesan minat luaran dan dalaman seseorang individu bagi mengembangkan semangat individu lain untuk mencapai sasaran yang telah ditetapkan. Motivasi guru amat dipengaruhi oleh kepimpinan guru besar dan amalan kepimpinan guru besar dilihat sebagai pendorong bagi motivasi para guru (Anis Salwa \& Siti Noor, 2018). Dalam hal ini, kepimpinan adalah keupayaan seseorang bagi mempengaruhi, menggerakkan dan memotivasikan orang lain dengan menggunakan keupayaan dan kebolehan diri mereka dalam melaksanakan sesuatu tugas (Eyal \& Roth, 2010).

Seorang pemimpin memainkan peranan yang sangat penting dalam memenuhi keperluan guru ke arah pencapaian prestasi cemerlang dalam organisasi. Kewibawaan seseorang pemimpin menjadi aspek yang paling penting kepada kecemerlangan organisasi (Baskaran \& A. Hamid, 2020). Kepimpinan distributif memenuhi amalan kepimpinan semasa di mana perkongsian kuasa dapat memudahkan pengurusan dan seterusnya mampu menyuntik motivasi di kalangan para guru bagi merealisasikan matlamat sekolah.

\section{Perkembangan Teori Kepimpinan}

Sejak beberapa dekad yang lalu, teori kepimpinan telah melalui pelbagai perubahan signifikan (Ramaiah, 2009). Menurut Hoy dan Miskel (2005), secara umumnya teori-teori kepimpinan dapat dibahagikan kepada dua kategori iaitu teori kepimpinan tradisional dan teori kepimpinan semasa. Pada peringkat awal, teori kepimpinan memberi tumpuan pada ciri yang membezakan antara pemimpin dengan pengikutnya dan menyebabkan kemunculan teori tradisional seperti teori Tret, teori Tingkah Laku dan teori Situasi (Zaidatol, 2003). Teori awal diberi tumpuan pada ciri pemimpin berkesan manakala teori semasa seperti teori Transformasi dan Teori Distributif mengalih tumpuan pada cara memimpin dengan berkesan (Noriati, Boon, \& Wong, 2010). Butiran lanjut tentang perkembangan teori kepimpinan seperti yang ditunjukkan dalam Rajah 1.

Rajah 1: Perkembangan Teori Kepimpinan

\begin{tabular}{|c|c|c|c|c|c|}
\hline Skop & \multicolumn{5}{|c|}{ Perkembangan } \\
\hline Zaman & \multicolumn{2}{|c|}{ Industri } & \multicolumn{3}{|c|}{ Pengetahuan } \\
\hline Elemen & Individu & 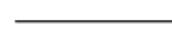 & $\rightarrow$ Situasi - & $\longrightarrow$ & Pasukan \\
\hline Jenis & Traits $\longrightarrow$ & Tingkahlaku & $\rightarrow$ Situasi $\longrightarrow$ & Transformasi & $\longrightarrow$ Distributif \\
\hline \multirow{6}{*}{ Kepemimpinan } & Bingham (1927) & Bass (1960) & Stogdill (1959) & House (1977) & Groon (2000) \\
\hline & & Likert (1961) & Katz \& Kahn & Bass (1985) & Leithwood (2000) \\
\hline & & Blake \& Mouton & (1978) & & Spillance (2001) \\
\hline & & (1964) & Hersey \& & & Harris (2002) \\
\hline & & McGregor (1966) & Blanchard & & Hulpia (2009) \\
\hline & & & $(1969,1977)$ & & \\
\hline $\begin{array}{l}\text { Golongan } \\
\text { dipentingkan }\end{array}$ & Pemimpi & 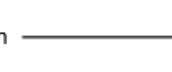 & $\rightarrow$ Situasi & $\rightarrow$ & Pengikut \\
\hline
\end{tabular}

Sumber: Siva \& Khuan (2012) 


\section{Kepimpinan Distributif}

Kepimpinan menggambarkan suatu elemen yang sangat mustahak dalam pengurusan sekolah. Kemampuan seorang pemimpin adalah memiliki bakat dalam dirinya untuk menjadi seorang pengurus yang efektif. Seorang pemimpin memerlukan kebolehan merancang, menyusun dan mengawal dalam sesuatu organisasi. Pemimpin sekolah pula perlu bijak mengamalkan kepimpinan distributif untuk menjayakan pelaksanaan Pelan Pembangunan Pendidikan Malaysia 2013-2025. Menurut Azhar et al. (2016), kepimpinan distributif merupakan kepimpinan yang mengandungi aspek teori kepimpinan popular yang lain. Kepimpinan distributif adalah satu pengagihan kerja, kuasa, tanggungjawab dan bidang daripada pemimpin kepada kakitangan dibawah selian mereka. Menurut Gronn (2002), kepimpinan distributif merupakan satu interaksi atau hubungan yang membantu menyatukan kepakaran dalam kalangan ahli dalam sesebuah organisasi dan juga membantu untuk mengurangkan konflik dalam organisasi. Perkongsian tugas akan membantu bagi melahirkan persefahaman antara individu yang menjalankan tugas bersama. Kepimpinan sokong dan membolehkan penglibatan guru dalam organisasi mempunyai hubungan yang positif dengan kepuasan dan komitmen kerja organisasi. Penyertaan guruguru dalam organisasi mempunyai hubungan yang positif serta dapat meningkatkan komitmen para guru, sekali gus kepimpinan yang memberi galakan akan mempengaruhi kesepaduan organisasi. Kepimpinan distributif juga merupakan salah satu proses yang sangat praktikal dan ia digunakan sebagai amalan bagi menjaga persekitaran organisasi yang sihat secara kolaborasi bersama.

Teori kepimpinan distributif merupakan pendekatan kepimpinan yang merangkumi pemimpin, pengikut dengan situasi organisasi melalui jalinan yang efektif. Jalinan sebegini akan dapat dilahirkan di sesebuah organisasi dengan kerjasama serta perlakuan yang selaras. Teori kepimpinan distributif juga menjadi amalan kepimpinan yang menyatukan semua kepakaran kepimpinan untuk tujuan kecemerlangan. Sesebuah organisasi yang mengamalkan perkongsian kepimpinan mampu meningkatkan inovasi serta menjayakan organisasi. Dalam masa yang sama, gaya kepimpinan distributif ini juga dapat meningkatkan keberkesanan guru dalam melaksanakan aktiviti pengajaran dan pembelajaran di sekolah selain dapat menjadi pemimpin yang berkesan sama ada kepada murid di sekolah mahupun kepada rakan guru yang lain.

Menurut Harris dan Spillane (2008), kepimpinan distributif dikatakan satu rangkaian individu atau kumpulan yang berinteraksi antara satu sama lain untuk kepentingan sesebuah organisasi. Gronn (2002), pula berpendapat kepimpinan distributif merupakan perhubungan yang membantu bagi penggabungan kualiti kerja dalam kalangan organisasi dan ia turut menyumbang untuk kurangkan konflik. Maksud kepimpinan distributif ialah amalan kepimpinan sekolah yang berkongsi tugas dan tanggungjawab secara holistik untuk meningkatkan motivasi guru dalam menjayakan proses pengurusan sekolah.

\section{Motivasi}

Motivasi merupakan sesuatu pendorongan individu atau kumpulan bagi melaksanakan sesuatu atau untuk mencapai sesuatu matlamat tertentu. Menurut Kreitner dan Kinicki (2007), motivasi membawa definisi sebagai sesuatu proses psikologi yang dapat memberi atau menyumbangkan kuasa, hala tuju dan usaha sukarela yang berterusan bagi mengecapi sesuatu matlamat yang ditetapkan. Motivasi merupakan satu aspek yang mustahak dalam menentukan pembelajaran yang sempurna. Hal ini kerana motivasi merupakan suatu cara pengajaran yang boleh mengasah minat pelajar dalam mata pelajaran yang dipelajari. Motivasi adalah keadaan dalaman seseorang yang membangkitkan, mengarah dan tingkah laku secara berterusan. Proses ini harus dikuasai atau difahami oleh pengurus untuk memperkesankan pekerja ke arah pencapaian objektif. Selain itu, motivasi juga merupakan satu proses yang mengambil kira sifat berhati-hati individu, usaha yang berterusan dan arahan bagi mencapai objektif yang ditetapkan.

Motivasi adalah pendorong atau perangsang yang bakal menimbulkan kegigihan tingkah laku untuk melaksanakan atau mengarahkan sesuatu tindakan bagi mencapai sesuatu tujuan yang ingin dicapai. Motivasi kerja guru sangat penting bagi melaksanakan urusan dan keberhasilan dari setiap sistem pendidikan. Ia merupakan rangsangan yang dapat membentuk dengan mengerakkan dan mempengaruhi 
guru untuk melaksanakan tugas dan tanggungjawab dengan baik dan bersesuaian dengan tujuan yang telah disasarkan. Motivasi kerja merangkumi faktor internal iaitu sumber dari dalam individu dan faktor eksternal yang merangkumi sumber dari luar individu. Motivasi kerja berkait rapat oleh faktor-faktor dalaman dan luaran iaitu pandangan mengenai diri sendiri, harga diri, harapan, peribadi, keutuhan, keinginan, kepuasan kerja, dan prestasi kerja yang dihasilkan oleh faktor internal. Kepentingan motivasi guru, kepimpinan guru dan kemahiran guru membuat keputusan akan memberikan kesedaran kepada golongan kepimpinan tertinggi sekolah yang mana perlu ditekankan dalam kalangan warga pendidik di sekolah. Ia penting agar matlamat meningkatkan pencapaian akademik murid dan sekolah akan dapat dicapai dengan lebih realistik dan memuaskan.

Menurut Morey Stettner (2005), motivasi dibahagikan kepada dua kategori jangka pendek iaitu memastikan peserta kumpulan melaksanakan tanggungjawab yang penuh bersemangat dan berdedikasi. Seterusnya motivasi jangka panjang pula menentukan keinginan ahlinya kekal bersama pasukannya untuk membimbing menjadi lebih berjaya. Teori motivasi Frederick Herzberg (1959) digunakan sebagai skop kedua dalam analisis ini. Teori motivasi yang dikemukakan oleh Frederick Herzberg (1959) mempunyai dua komponen iaitu faktor pendorong (Motivator factor) dan faktor pemeliharaan (Hygiene factor).

\section{Gaya Kepimpinan dan Motivasi}

Murgaya dan Hamid (2020), mengenal pasti hubungan gaya kepimpinan karismatik pentadbir dan motivasi guru di sekolah. Responden kajian ini terdiri daripada 92 orang guru yang berkhidmat di dua buah sekolah rendah berprestasi tinggi di daerah Petaling Utama Negeri Selangor. Keputusan ujian Korelasi Pearson membuktikan bahawa amalan gaya kepimpinan karismatik pentadbir mempunyai hubungan yang signifikan dengan tahap motivasi guru. Hubungan positif ini menunjukkan semakin baik kepimpinan yang ditunjukkan oleh pemimpin, maka semakin tinggi motivasi guru di sekolah tersebut. Dapatan kajian ini selari dengan kajian Norlela (2011) yang menunjukkan amalan kepimpinan karismatik dalam kalangan pemimpin organisasi di sesebuah institusi pendidikan menjadi kunci kejayaan visi dan misi organisasi tersebut. Selain itu dapatan kajian ini juga selari dengan pendapat Berson dan Bruce (2004) yang menyatakan gaya kepimpinan yang diamalkan oleh pengurus dalam organisasi merupakan salah satu faktor yang memberi kesan kepada motivasi, kreativiti, kepuasan kerja dan kejayaan organisasi.

Fei dan Han (2018), mengkaji tentang hubungan kepimpinan pengetua dengan motivasi guru. Kajian ini meliputi seramai 188 responden dari sekolah-sekolah menengah daerah Sri Aman, Sarawak. Responden dipilih secara kaedah rawak mudah. Dapatan kajian ini menunjukkan hubungan kepimpinan pengetua dan motivasi guru adalah pada tahap tinggi. Analisis kajian mendapati terdapat hubungan positif yang lemah dan signifikan antara hubungan kepimpinan pengetua dan motivasi guru. Pengkaji menyatakan bahawa kajian ini selari dengan dapatan kajian Zuraidah (2002). Kajian ini dirumuskan kepiminan distributif mampu melahirkan motivasi diri dalam kalangan guru.

Selain itu, Logavalli dan Jamallul Lail (2018) telah menjalankan kajian untuk mengenal pasti tahap amalan kepimpinan distributif penyelia di Sekolah Dalam Hospital (SDH) di Malaysia menunjukkan amalan kepimpinan distributif penyelia SDH berada pada tahap yang tinggi. Dapatan kajian menunjukkan persepsi responden terhadap keempat-empat dimensi dalam kepimpinan distributif iaitu Visi, Misi dan Matlamat Sekolah, Budaya Sekolah, Perkongsian Tanggungjawab serta Amalan Kepimpinan berada pada tahap yang tinggi dan ia membantu untuk memotivasikan diri guru-gurunya.

Menurut kajian Azhar dan Ramli (2016) terhadap 400 orang yang mengajar di sekolah menengah di kawasan pasukan. Apabila dikaji, di Semenanjung Malaysia telah didapati bahawa pandangan guru-guru sekolah menengah terhadap pengaruh kepimpinan distributif pengetua adalah berada pada peringkat yang tinggi. Pandangan skor yang paling tinggi yang dijawab oleh responden terhadap kepimpinan distributif pengetua sekolah mereka berdasarkan dimensi visi, misi dan matlamat. Azhar dan Ramli (2016) menyatakan skor min yang tinggi didapati guru bersetuju bahawa pengetua di sekolah mereka memastikan untuk menetapkan dan berkongsi visi, misi dan matlamat bersama mereka. 
Paul (2015) melibatkan guru daripada 36 buah sekolah menengah di Bandar Arizona dijalankan bagi mengenal pasti hubungan amalan kepimpinan pengetua dalam mempengaruhi motivasi guru untuk bersedia mengambil peluang dalam pembangunan professional kendiri bagi menguasai teknologi terkini. Paul (2015), mendapati kepimpinan pengetua amat mempengaruhi tahap motivasi guru untuk mendapatkan ilmu dalam memantapkan profesionalisme perguruan diri masing-masing. Hasil daripada kajian-kajian lepas menunjukkan bahawa motivasi merupakan aspek yang sangat penting bagi mencapai kejayaan.

Dalam pada itu, amalan kepimpinan dalam kalangan pemimpin sekolah yang dikaji juga adalah tinggi. Sementara itu, Jamallulail et al. (2013) dalam kajian mereka menjelaskan bahawa terdapat hubungan yang sangat signifikan antara kepimpinan distributif guru besar dengan motivasi kerja dalam kalangan guru. Kepimpinan bersama antara guru besar dan guru di sekolah dapat meningkatkan motivasi kerja guru ke tahap yang lebih memuaskan. Kesanggupan guru besar untuk berkongsi nilai kepimpinan di sekolah turut mewujudkan rasa penghargaan dalam diri guru khususnya yang berkaitan dengan peluang guru untuk membuat keputusan bagi menyelesaikan isu, permasalahan dan cabaran yang mereka hadapi dalam tugas mendidik di sekolah.

Akhir sekali, kajian Silins dan Mulford (2002), membuktikan amalan kepimpinan distributif guru besar pada tahap yang tinggi dapat memberi kesan secara langsung dalam motivasi guru. Dapatan ini disokong oleh kajian yang dijalankan oleh Chin dan Jamalul Lail (2018) ke atas 181 orang yang mengajar di sekolah menengah kerajaan di Daerah Sri Aman, Sarawak secara kuantitatif dan menggunakan kaedah tinjauan untuk mengetahui amalan kepimpinan distributif pengetua dan hubungannya dengan motivasi kerja guru telah mendapati bahawa pandangan guru-guru terhadap kepimpinan distributif pengetua terletak di tahap yang tinggi. Berdasarkan kajian tersebut, dimensi visi, misi dan matlamat merupakan dimensi kepimpinan distributif yang diamalkan oleh pengetua berdasarkan persepsi para responden berbanding dengan dimensi lain dalam kepimpinan distributif.

\section{Kesimpulan}

Kesimpulannya, analisis dan ulasan kajian sistematik ini telah dapat meneroka pengaruh kepimpinan distributif terhadap motivasi guru. Ulasan kajian lepas mendapati bahawa kepimpinan distributif mempunyai hubungan yang signifikan terhadap motivasi guru. Berdasarkan kajian-kajian lepas yang telah dibuat ke atas kajian-kajian yang berkaitan dengan kepimpinan distributif dan motivasi guru, dapat dirumuskan bahawa kepimpinan distributif merupakan satu elemen yang penting untuk meningkatkan motivasi subordinat di sesebuah organisasi. Akhir sekali, aspek kepimpinan distributif dan motivasi guru penting untuk dikaji kerana ia memberikan manfaat kepada kejayaan Pendidikan di negara kita seperti mana yang dinyatakan dalam Pelan Pembangunan Pendidikan Malaysia (PPPM 2013-2025).

\section{Rujukan}

Azhar bin Harun \& Ramli bin Basri. (2016). Hubungan kepemimpinan distrubutif pengetua dan kepemimpinan guru di sekolah menengah. Jurnal Pengurusn dan Kepimpinan Pendidikan, 29(1), $105-122$.

Al Ramaiah. (2009). Kepimpinan Pendidikan: Cabaran Masa Kini. Petaling Jaya: IBS Buku Sdn. Bhd.

Anis Salwa Abdullah \& Siti Noor Ismail. (2018). Interaksi Kepimpinan Perkongsian Dan Kepimpinan Sahih Guru Besar Terhadap Motivasi Dan Tekanan Kerja Guru. Jurnal Kepimpinan Pendidikan, $5(1), 16-32$

Baskaran, K., \& A. Hamid, A. H. (2020). Amalan kepimpinan instruksional pengetua di sekolah menengah di bandar Banting. International Journal of Education and Pedagogy, 2(1), 264-284.

Berson, Y. \& Bruce, J. A. (2004). Transformational leadership and the dissemination of organization goals: A case study of a telecommunication firm. The Leadership Quarterly, 15(5), 625-646. 
Bush, T. \& Ng, A. Y. M. (2019). Distributed Leadership and the Malaysia Education Blueprint: From Prescription to Partial School-Based Enactment in a Highly Centralised Context. Journal of Educational Administration, 57(3), 279-295

Chin, K. S., \& Jamalul Lail, A. W. (2018). Amalan kepimpinan distributif pengetua dan hubungan dengan kepuasan kerja guru di daerah Sri Aman, Sarawak. ICOFEA 2018 Conference Proceeding

Ejimabo N., O. (2015). The Influence of Decision Making in Organizational Leadership and Management Activities. Jurnal Entrepreneurship Organization Management, 4, 138.

Eyal. O. Roth. G. (2010). Principals' Leadership and Teachers' Motivation. Journal of Educational Administration, 256-275.

Fei, E. L. E., \& Han, C. G. K. (2018). Hubungan Kepimpinan Pengetua Dengan Motivasi Guru. International Journal of Education, Psychology and Counseling, 2(5),145-159.

Fullan, M., Hill, P., \& Crevola, C. (2006). Breakthrough. Thousands Oaks, CA: Corwin Press.

Gronn, P. (2002). Distributed Leadership as a Unit of Analysis, The Leadership Quarterly, 13, 423-451.

Harris, A. (2008). Distributed School Leadership. Developing tomorrow's leader.London: Routledge.

Herzberg, F., Masner, B. \& Synderman, B. (1959). The Motivation to Work. New York: John Wiley and Sons.

Hoy, W.K. \& Miskel, C.G. (2005). Educational administration: Theory, Research, And Practice (7th ed.). New York: McGraw Hill.

Jamalullail, A. W., Aida Hanim A. H., Surayati, Z. \& Md Fuad, M. R. (2013). The Relationship between Headteachers' Distributed Leadership Practices and Teachers' Motivation in National Primary Schools. Asian Social Science, 9(16), 161-167.

Kreitner, R. \& Kinicki, A. (2007). Organizational Behavior. (7th ed). New York: Mc Graw Hill.

Logavalli, B., \& Jamallul Lail, A.W. (2018). Amalan Kepimpinan Distributif Penyelia dan Hubungannya dengan Motivasi Guru di Sekolah Dalam Hospital (SDH) di Malaysia. 11th Language for Specific Purposes International Conference. Universiti Teknologi Malaysia. Johor.

Mad Shah, Ishak. (2006). Kepimpinan dan hubungan interpersonal dalam organisasi. Penerbit UTM, Skudai, Johor Bahru.

Murgaya, Thaamarai Selvi; A. Hamid, Aida Hanim.(2020). Kepimpinan Karismatik Pentadbir dan Hubungannya Terhadap Motivasi Guru Sekolah Rendah. International Journal Of Education and Pedagogy, 2(4), 415-429.

Noriati A. Rashid, Boon Pong Ying \& Wong Kiet Wah (2010). Asas Kepimpinan dan Perkembangan Profesional Guru. Selangor Darul Ehsan: Oxford Fajar Sdn. Bhd.

Norasmah Othman \& Rofilah Md. Said. (2013). Tahap kesediaan guru sekolah menengah harian mengamalkan kepimpinan tersebar. Jurnal Teknologi 64(1), 93-100.

Norlela Ali. (2011). Pengaruh Kepimpinan Karismatik Pengetua Ke Atas Motivasi Guru, Univertisi Utara Malaysia, Kedah.

Paul, T. (2015). How Principal Leadership Influences Teacher Motivation to Seek Out Professional Development Opportunities on New Technology. Grand Canyon University.

Siva Rabindarang \& Khuan, W. B. (2012). Kerangka Teoritikal Pengaruh Kepimpinan Distributif Terhadap Komitmen Organisasi dan Tekanan kerja dalam organisasi Teknik dan Vokasional. 5TH UPSI-UPI Conference on Education 2012 1st-3rd Oktober 2021, Hotel Concorde Shah Alam, Malaysia.

Siva Rabindarang. (2014). Kepimpinan Distributif, Komitmen Organisasi Dan Tekanan Kerja Di Kolej Vokasional, Malaysia. Universiti Pendidikan Sultan Idris.

Silins, H., \& Mulford, B. (2002). Leadership and school results. In K. Leithwood, \& P. Hallinger (Eds.), Second International Handbook of Educational Leadership and Administration (pp. 561-612). Norwell, MA: Kluwer Academic Publishers. http://dx.doi.org/10.1007/978-94-010$\underline{0375-9} 21$

Spillane,J.(2008).Leading and managing Educational Change :Enganging the Challenge in practice:presentation at NCCA Conference, October 2008. Carrickmacross, Co. Monaghan.

Zaidatol Akmaliah Lope Pihie, \& Foo Say Fooi. (2003). Pengurusan dan Kepimpinan pendidikan: Satu langkah ke hadapan: Penerbit Universiti Putra Malaysia.

Zuraidah bt. Abdullah. (2002). Kepemimpinan transformasi: Pembentukan Organisasi Pembelajaran Di Sebuah Sekolah Di Selangor. Kertas Projek Sarjana yang tidak diterbitkan. Universiti Malaya, Kuala Lumpur 